\title{
Effects of adaptation time and inclusion level of sugar beet pulp on nutrient digestibility and evaluation of ileal amino acid digestibility in pigs
}

\author{
Ze Yu Zhang ${ }^{1}$, Shuai Zhang', Chang Hua Lai', Jin Biao Zhao', Jian Jun Zang ${ }^{1}$, and Cheng Fei Huang ${ }^{1, *}$
}

\begin{abstract}
* Corresponding Author: Cheng fei Huang Tel: +86-6273-3688-010, Fax: +86-10-6273-3688, E-mail: chfhuang@126.com
\end{abstract}

'State Key Laboratory of Animal Nutrition, College of Animal Science and Technology, China Agricultural University, Beijing 100193, China

ORCID

Ze Yu Zhang

https://orcid.org/0000-0002-2541-7166

Shuai Zhang

https://orcid.org/0000-0001-5435-2640

Chang Hua Lai

https://orcid.org/0000-0002-6736-7179

Jin Biao Zhao

https://orcid.org/0000-0001-7900-0131

Jian Jun Zang

https://orcid.org/0000-0002-1613-6119

Cheng Fei Huang

https://orcid.org/0000-0002-4943-1472

Submitted Feb 28, 2018; Revised Jun 8, 2018; Accepted Jul 31, 2018
Objective: Two experiments were conducted to determine the effects of adaptation time and inclusion level of sugar beet pulp (SBP) on nutrient digestibility and to evaluate the ileal amino acid digestibility of SBP fed to pigs.

Methods: In Exp. 1, thirty-six crossbred barrows $(85.0 \pm 2.1 \mathrm{~kg})$ were allotted to 6 diets in a completely randomized design with six replicates per diet. Diets included a corn-soybean meal diet and 5 test diets containing $14.6 \%, 24.4 \%, 34.2 \%, 43.9 \%$, or $53.7 \%$ SBP, respectively. The adaptation time consisted $7,14,21$, or $28 \mathrm{~d}$ consecutively for each pig followed by $5 \mathrm{~d}$ for fecal collection. Feces were collected from d 8 to 13 , d 15 to 20 , d 22 to 27 , and d 29 to 34 , respectively. In Exp. 2, six pigs ( $35.1 \pm 1.7 \mathrm{~kg}$ ) with T-cannulas at the terminal ileum were fed to 3 diets in a replicated $3 \times 3$ Latin square design with 3 periods and 2 replicate pigs per diet. Each period consisted $5 \mathrm{~d}$ for diet adaptation followed by $2 \mathrm{~d}$ for digesta collection.

Results: The digestible energy (DE) value and the apparent total tract digestibility (ATTD) of gross energy (GE), dry matter (DM), ash, and organic matter in diets linearly decreased ( $\mathrm{p}<$ 0.05 ) as the adaptation time increased or as the dietary SBP increased, while the ATTD of neutral detergent fibre and acid detergent fibre in diets linearly increased $(\mathrm{p}<0.01)$ as the dietary SBP increased. The DE value and the ATTD of GE and crude protein (CP) in SBP linearly increased $(\mathrm{p}<0.05)$ as the adaptation time increased, while the ATTD of CP in SBP linearly decreased $(\mathrm{p}<0.01)$ as the inclusion level increased. The standardized ileal digestibility of Lys, Met, Thr, and Trp in SBP was 37.03\%, 51.62\%, 40.68\%, and 46.22\%, respectively.

Conclusion: The results of this study indicated that the ATTD of energy and nutrients were decreased as inclusion rate of SBP increased.

Keywords: Adaptation Time; Amino Acid; Digestibility; Inclusion Level; Pig; Sugar Beet Pulp

\section{INTRODUCTION}

Monogastric animals cannot secret endogenous enzymes into the small intestine to degrade dietary fiber, but the dietary fiber can be fermented in the hindgut of these animals [1]. Volatile fatty acids generated from fiber fermentation in the hindgut can provide $15 \%$ to $30 \%$ of the net energy requirements for maintenance in pigs [2-4]. However, diets with a high fiber content usually have low apparent total tract digestibility (ATTD) and apparent ileal digestibility (AID) of nutrients [5-7]. The magnitude of the negative effects of fiber on the nutrient digestibility may be affected by the inclusion level of dietary fiber [6]. Moreover, it usually takes some time for pigs and the microbiota in the hindgut to adapt to high fiber diets $[6,8,9]$. A previous study on pregnant sows reported that 10 days of adaptation to a diet with a high level fermentable non-starch polysaccharides (30\%) is needed [10]. Another study found that the gut microbiota in pigs need at least 3 weeks and up to 6 weeks to adapt to a new diet 
[8]. However, these studies were conducted with only one dietary fiber level. It is still not clear whether there is an interaction effect between the adaptation time of diets and the dietary fiber level. Sugar beet pulp (SBP) has comparable of gross energy (GE) and crude protein (CP) contents to corn grains [11]. The high fiber contents in SBP limit its utilization as an energy or protein source in swines' diet. In addition, little information is available on the nutritional values and digestibility of nutrients and amino acids (AA) of SBP in growing pigs. Therefore, the objectives of this study were: i) to test the hypothesis that there was an interaction effect of adaptation time and inclusion level of SBP on nutrient digestibility in pigs, and ii) to determine the ileal digestibility of $\mathrm{CP}$ and $\mathrm{AA}$ in SBP fed to growing pigs.

\section{MATERIALS AND METHODS}

The protocol for all animal procedures was approved by the Institutional Animal Care and Use Committee at China Agricultural University (Beijing, China).

Experiment 1: Effect of adaptation time and inclusion level of sugar beet pulp on energy value and nutrient digestibility in growing pigs

Experimental design and diets: Thirty-six crossbred barrows (Duroc $\times$ Landrace $\times$ Large White) with an average of $85.0 \pm 2.1$ $\mathrm{kg}$ body weight (BW) were allotted to a completely randomized design with 4 adaptation time and 6 diets. The adaptation time consisted 7, 14, 21, or $28 \mathrm{~d}$ consecutively for each pig, with feces collected from d 8 to 13,15 to 20,22 to 27 , and 29 to 34 , respectively. The experimental diets included a corn-soybean meal-based diet containing $76.6 \%$ corn, $21.0 \%$ soybean meal (SBM), $1.0 \%$ limestone, $0.6 \%$ dicalcium phosphate, $0.3 \%$ salt, and $0.5 \%$ vitamin-mineral premix. The 5 test diets were formulated by substituting the energy source of corn and SBM in the basal diet with $15 \%, 25 \%, 35 \%, 45 \%$, or $55 \%$ of SBP. The concentration of SBP was $14.6 \%, 24.4 \%, 34.2 \%, 43.9 \%$, and $53.7 \%$ in the five complete test diets, respectively. Vitamins and minerals were supplemented in all diets to meet or exceed the nutrient requirements for 75 to $100 \mathrm{~kg}$ barrows [11]. The GE and analyzed proximate compositions of corn and SBP were presented in Table 1 . The ingredient and analyzed compositions of six experimental diets are presented in Table 2.

Animal housing, feeding, and sample collection: All pigs were individually housed in stainless-steel metabolism crates $\left(1.4 \times 0.9 \times 0.7 \mathrm{~m}^{3}\right)$ at the Fengning Swine Research Unit of China Agricultural University (Chengde, China). The crates had adjustable sides and were in a room with temperature and light controlled at $22^{\circ} \mathrm{C} \pm 2.5^{\circ} \mathrm{C}$ and $12 \mathrm{~h}$ of light and $12 \mathrm{~h}$ of dark, respectively. Humidity varied from $55 \%$ to $65 \%$ during the experiment. An adjustable screen was placed under each crate for total feces collection. Pigs were acclimated to the new environment for $7 \mathrm{~d}$ and fed a commercial corn-SBM-based diet
Table 1. Analyzed composition of corn and sugar beet pulp (\%, as-fed basis) ${ }^{11}$

\begin{tabular}{|c|c|c|}
\hline Item & Corn & Sugar beet pulp \\
\hline Dry matter & 89.0 & 90.5 \\
\hline Ether extract & 3.3 & 0.8 \\
\hline Ash & 1.3 & 7.3 \\
\hline Organic matter & 87.7 & 83.2 \\
\hline Total dietary fibre & 10.2 & 58.7 \\
\hline Soluble dietary fibre & 0.5 & 23.9 \\
\hline Insoluble dietary fibre & 9.7 & 34.8 \\
\hline Neutral detergent fibre & 10.1 & 36.6 \\
\hline Acid detergent fiber & 3.1 & 22.2 \\
\hline Gross energy (kcal/kg) & 3,943 & 3,508 \\
\hline Crude protein & 8.4 & 8.5 \\
\hline \multicolumn{3}{|l|}{ Indispensable amino acid } \\
\hline Arg & 0.37 & 0.31 \\
\hline His & 0.24 & 0.22 \\
\hline Ile & 0.25 & 0.29 \\
\hline Leu & 1.01 & 0.54 \\
\hline Lys & 0.24 & 0.45 \\
\hline Met & 0.16 & 0.07 \\
\hline Phe & 0.38 & 0.36 \\
\hline Thr & 0.29 & 0.34 \\
\hline Trp & 0.06 & 0.08 \\
\hline Val & 0.41 & 0.48 \\
\hline \multicolumn{3}{|l|}{ Dispensable amino acid } \\
\hline Ala & 0.45 & 0.51 \\
\hline Asp & 0.53 & 0.63 \\
\hline Cys & 0.19 & 0.07 \\
\hline Glu & 1.37 & 0.94 \\
\hline Gly & 0.29 & 0.34 \\
\hline Pro & 0.71 & 0.46 \\
\hline Ser & 0.36 & 0.37 \\
\hline Tyr & 0.27 & 0.36 \\
\hline
\end{tabular}

${ }^{1)}$ Data are the mean of duplicate analyses of each ingredient.

before the beginning of the experiment. Experimental diets were daily offered to pigs at a level of $3 \%$ of their initial BW and provided in 2 equal meals at $0830 \mathrm{~h}$ and $1630 \mathrm{~h}$. Feed refusals were collected and weighed daily. Pigs were fed the same experimental diets throughout the whole experimental period. The adaptation time lasted for 7 days and then feces were quantitatively collected for 5 days during each collection period. Feces were consecutively collected from d 8 to 13 , d 15 to 20 , d 22 to 27 , and d 29 to 34 , respectively. Fresh feces were stored at $-20^{\circ} \mathrm{C}$ immediately after collected. At the end of each collection period, the collected feces were weighed and thawed, and then homogenized thoroughly within pig and collection period. A sub-sample of feces from each pig in each collection period was dried in a forced-air oven at $65^{\circ} \mathrm{C}$ for $72 \mathrm{~h}$. Dried feces were ground through a 1-mm screen before chemical analysis. All pigs had ad libitum access to water via a drinking nipple.

Chemical analysis: Samples were analyzed for GE via an adiabatic oxygen bomb calorimeter (Parr 6300 Calorimeter; 
Table 2. Ingredient and analyzed composition of experimental diets in Exp. 1 (\%, as-fed basis) $)^{1)}$

\begin{tabular}{|c|c|c|c|c|c|c|}
\hline \multirow{2}{*}{ Items } & \multicolumn{6}{|c|}{ Inclusion level of sugar beet pulp (\%) } \\
\hline & 0.0 & 14.6 & 24.4 & 34.2 & 43.9 & 53.7 \\
\hline \multicolumn{7}{|l|}{ Ingredient } \\
\hline Soybean meal, $48 \%$ CP & 21.0 & 17.9 & 15.8 & 13.7 & 11.6 & 9.5 \\
\hline Sugar beet pulp & - & 14.6 & 24.4 & 34.2 & 43.9 & 53.7 \\
\hline Limestone & 1.0 & 1.0 & 1.0 & 1.0 & 1.0 & 1.0 \\
\hline Salt & 0.3 & 0.3 & 0.3 & 0.3 & 0.3 & 0.3 \\
\hline Vitamin-mineral premix ${ }^{2)}$ & 0.5 & 0.5 & 0.5 & 0.5 & 0.5 & 0.5 \\
\hline \multicolumn{7}{|l|}{ Analyzed chemical composition } \\
\hline DM & 88.4 & 87.8 & 87.8 & 88.2 & 88.6 & 88.8 \\
\hline$C P$ & 16.8 & 15.1 & 14.3 & 13.6 & 12.6 & 12.2 \\
\hline GE (kcal/kg) & 3,867 & 3,804 & 3,757 & 3,694 & 3,706 & 3,694 \\
\hline
\end{tabular}

"All data are the results of a chemical analyses conducted in duplicate. DM, dry matter; CP, crude protein; OM, organic matter; NDF, neutral detergent fibre; ADF, acid detergent fibre; GE, gross energy.

2) Provided the following quantities per $\mathrm{kg}$ of complete diet: $\mathrm{Mn}, 50 \mathrm{mg}(\mathrm{MnO}) ; \mathrm{Fe}, 125 \mathrm{mg}\left(\mathrm{FeSO}_{4} \cdot \mathrm{H}_{2} \mathrm{O}\right) ; \mathrm{Zn}, 125 \mathrm{mg}(\mathrm{ZnO}) ; \mathrm{Cu}_{1} 150 \mathrm{mg}\left(\mathrm{CuSO}_{4} \cdot 5 \mathrm{H}_{2} \mathrm{O}\right) ; \mathrm{l}, 50 \mathrm{mg}\left(\mathrm{Cal}_{2}\right) ; \mathrm{Se}, 0.30$ $\mathrm{mg}\left(\mathrm{Na}_{2} \mathrm{SeO}_{3}\right)$; retinyl acetate, 4,500 IU; cholecalciferol, 1,350 IU; DL- $\alpha$-tocopheryl acetate, $13.5 \mathrm{mg}$; menadione sodium bisulphite complex, $2.7 \mathrm{mg} ;$ niacin, $18 \mathrm{mg}$; vitamin $B_{12}, 27.6 \mu$; thiamine, $0.6 \mathrm{mg}$; pyridoxine, $0.9 \mathrm{mg}$; riboflavin, $1.8 \mathrm{mg}$; D-Ca-pantothenate, $10.8 \mathrm{mg}$; nicotinic acid.

Parr Instrument Company, Moline, IL, USA). Other analysis including DM, CP, and ash analyzed according to AOAC [12]. The ether extract (EE) was analyzed by a previous method [13]. Total dietary fiber (TDF) and insoluble dietary fiber (IDF) in SBP or corn grain were also determined according to AOAC [12]. The concentration of soluble dietary fiber (SDF) was calculated as the difference between TDF and IDF. Neutral detergent fiber (NDF) and acid detergent fiber (ADF) were determined using filter bags and fiber analyzer equipment (Fiber Analyzer; ANKOM Technology, Macedon, NY, USA) following a modification of the procedures [14]. The concentration of NDF was analyzed using heat-stable $\alpha$-amylase and sodium sulfite without correction for insoluble ash. Organic matter $(\mathrm{OM})$ was calculated as the difference between $\mathrm{DM}$ and ash. All chemical analyses were conducted in duplicates.

Calculations: The digestibility of GE and other nutrients in feed and SBP were calculated according to the difference method [15], and the DE and metabolizable energy were calculated by multiplying the GE content and the digestibility of GE in feed or SBP, respectively.

\section{Experiment 2: Amino acid digestibility in sugar beet pulp}

Experimental design and diets: Six pigs $(35.1 \pm 1.7 \mathrm{~kg} \mathrm{BW})$ fitted with $\mathrm{T}$-cannulas at the terminal ileum according to the method [16] were fed to 3 diets in replicated $3 \times 3$ Latin square design with 3 periods and 2 replicate pigs per diet in each period. The
3 experimental diets included a corn diet containing 96.6\% corn, a SBP diet containing 50\% corn starch, 30\% SBP, 15\% sucrose, and $2 \%$ soybean oil, and a nitrogen-free ( $\mathrm{N}$-free) diet containing $73.35 \%$ corn starch, $15 \%$ sucrose, $4 \%$ acetate cellulose, and $3 \%$ soybean oil. The $\mathrm{N}$-free diet was used to determine the basal ileal endogenous $\mathrm{N}$ losses. Chromic oxide, as an indigestible index, was included in all diets $(0.3 \%)$ for calculating the ileal digestibility of AA. Vitamins and minerals were supplemented in all diets to meet or exceed the estimated nutrient requirements for growing pigs [11]. The analyzed AA contents of SBP are presented in Table 1. Ingredients, analyzed CP, and AA compositions of the 3 experimental diets are presented in Table 3.

Animal housing, feeding, and sample collection: All pigs were individually housed in stainless-steel metabolism crates (1.4× $\left.0.9 \times 0.7 \mathrm{~m}^{3}\right)$ at the metabolism room located at China Agricultural University. After $10 \mathrm{~d}$ of recovery from the T-cannulas surgery at the terminal ileum, pigs were fed experimental diets. Each period consisted $5 \mathrm{~d}$ for diet adaptation followed by $2 \mathrm{~d}$ for digesta collection.

Experimental diets were daily offered to pigs at a level of $4 \%$ of their initial BW and provided in 2 equal meals at $0730 \mathrm{~h}$ and $1630 \mathrm{~h}$ each day. The digesta collection lasted for $9 \mathrm{~h}$ daily beginning at $0800 \mathrm{~h}$ according to the procedures described by Stein et al [16]. On $\mathrm{d} 6$ and 7, plastic bags were attached to the barrel of the cannulas and removed whenever they were filled with digesta and then stored at $-20^{\circ} \mathrm{C}$. At the end of the experiment, digesta samples were thawed, mixed by pig and 
Table 3. The ingredient and analyzed composition of the experimental diets in Exp. 2 (\%, as-fed)

\begin{tabular}{|c|c|c|c|}
\hline \multirow{2}{*}{ Items } & \multicolumn{3}{|c|}{ Diets } \\
\hline & Corn & Sugar beet pulp & $\mathrm{N}$-free \\
\hline \multicolumn{4}{|l|}{ Ingredient } \\
\hline Corn & 96.6 & - & - \\
\hline Sugar beet pulp & - & 30.0 & - \\
\hline Corn starch & - & 50.0 & 73.35 \\
\hline Soybean oil & - & 2.0 & 3.0 \\
\hline Sucrose & - & 15.0 & 15.0 \\
\hline Acetate cellulose $e^{1)}$ & - & - & 4.0 \\
\hline Dicalcium phosphate & 1.7 & 1.5 & 2.5 \\
\hline Limestone & 0.6 & 0.4 & 0.5 \\
\hline Sodium chloride & 0.3 & 0.3 & 0.45 \\
\hline Chromic oxide & 0.3 & 0.3 & 0.3 \\
\hline Potassium carbonate & - & - & 0.3 \\
\hline Magnesium oxide & - & - & 0.1 \\
\hline Vitamin-mineral premix ${ }^{2)}$ & 0.5 & 0.5 & 0.5 \\
\hline \multicolumn{4}{|l|}{ Analyzed composition } \\
\hline Crude protein & 8.03 & 2.54 & 0.35 \\
\hline \multicolumn{4}{|l|}{ Indispensable amino acid } \\
\hline $\operatorname{Arg}$ & 0.35 & 0.08 & 0.01 \\
\hline His & 0.23 & 0.06 & 0.01 \\
\hline Ile & 0.24 & 0.08 & 0.01 \\
\hline Leu & 0.96 & 0.15 & 0.05 \\
\hline Lys & 0.24 & 0.12 & 0.01 \\
\hline Met & 0.14 & 0.01 & 0.00 \\
\hline Phe & 0.33 & 0.11 & 0.03 \\
\hline Thr & 0.25 & 0.09 & 0.01 \\
\hline Trp & 0.05 & 0.01 & 0.00 \\
\hline Val & 0.37 & 0.14 & 0.01 \\
\hline \multicolumn{4}{|l|}{ Dispensable amino acid } \\
\hline Ala & 0.42 & 0.15 & 0.02 \\
\hline Asp & 0.49 & 0.18 & 0.02 \\
\hline Cys & 0.16 & 0.01 & 0.11 \\
\hline Glu & 1.21 & 0.28 & 0.03 \\
\hline Gly & 0.26 & 0.10 & 0.01 \\
\hline Pro & 0.63 & 0.14 & 0.02 \\
\hline Ser & 0.34 & 0.11 & 0.01 \\
\hline Tyr & 0.26 & 0.10 & 0.02 \\
\hline
\end{tabular}

1) Made by Chemical Reagents Company (Beijing, China).

2) Provided the following quantities per $\mathrm{kg}$ of complete diet: $\mathrm{Mn}, 50 \mathrm{mg}(\mathrm{MnO})$; $\mathrm{Fe}, 125 \mathrm{mg}\left(\mathrm{FeSO}_{4} \cdot \mathrm{H}_{2} \mathrm{O}\right) ; \mathrm{Zn}, 125 \mathrm{mg}(\mathrm{ZnO}) ; \mathrm{Cu}, 150 \mathrm{mg}\left(\mathrm{CuSO}_{4} \cdot 5 \mathrm{H}_{2} \mathrm{O}\right) ; \mathrm{l}, 50 \mathrm{mg}$ $\left(\mathrm{Cal}_{2}\right)$; $\mathrm{Se}, 0.30 \mathrm{mg}\left(\mathrm{Na}_{2} \mathrm{SeO}_{3}\right)$; retinyl acetate, 4,500 IU; cholecalciferol, 1,350 IU; $\mathrm{DL}$ - $\alpha$-tocopheryl acetate, $13.5 \mathrm{mg}$; menadione sodium bisulphite complex, 2.7 $\mathrm{mg}$; niacin, $18 \mathrm{mg}$; vitamin $\mathrm{B}_{12}, 27.6 \mu \mathrm{g}$; thiamine, $0.6 \mathrm{mg}$; pyridoxine, $0.9 \mathrm{mg}$; riboflavin, $1.8 \mathrm{mg}$; D-Ca-pantothenate, $10.8 \mathrm{mg}$; nicotinic acid.

period, subsampled, and lyophilized in a vacuum-freeze dryer (Tofflon Freezing Drying Systems, Minhang District, Shanghai, China). All pigs had ad libitum access to water via a drinking nipple.

Chemical analysis: Before analysis, SBP, diets, and digesta were ground through a 1-mm screen and mixed thoroughly. Analyses of the AA content in all samples were conducted according to Li et al [17]. For all AA, excluding Met, Cys, and
Trp, samples were hydrolyzed with $6 \mathrm{~N} \mathrm{HCl}$ at $110^{\circ} \mathrm{C}$ for 24 $\mathrm{h}$ and then analyzed using an Amino Acid Analyzer (Hitachi L-8900; Hitachi Ltd., Tokyo, Japan). The sulfur AA (Met and Cys) were subjected to cold performic acid oxidation overnight and hydrolyzed with $7.5 \mathrm{~N} \mathrm{HCl}$ at $110^{\circ} \mathrm{C}$ for $24 \mathrm{~h}$ before measured using an Amino Acid Analyzer (Hitachi L-8900, Hitachi Ltd., Japan). Estimate of Trp was made by hydrolyzing the sample with $\mathrm{LiOH}$ for $22 \mathrm{~h}$ at a constant temperature of $110^{\circ} \mathrm{C}$ and then analyzed using High Performance Liquid Chromatography (Agilent 1200 Series; Agilent Technologies Inc., Santa Clara, CA, USA). Analysis of Cr in the diets and digesta was conducted using a polarized Zeeman Atomic Absorption Spectrometer (Hitachi Z2000; Hitachi Ltd., Japan) after nitric acid-perchloric acid wet ash sample preparation. All analyses were conducted in duplicate.

Calculations: The AID and SID of AA was calculated using the following equation [18]:

$$
\mathrm{AID}=\left[1-\left(\mathrm{AA}_{\mathrm{d}} / \mathrm{AA}_{\mathrm{f}}\right) \times\left(\mathrm{Cr}_{\mathrm{f}} / \mathrm{Cr}_{\mathrm{d}}\right)\right] \times 100 \%,
$$

where $\mathrm{AA}_{\mathrm{d}}$ and $\mathrm{Cr}_{\mathrm{d}}$ are the concentrations of $\mathrm{AA}$ and $\mathrm{Cr}$ in the ileal digesta $\left(\mathrm{g} / \mathrm{kg}\right.$ of DM) and $\mathrm{AA}_{\mathrm{f}}$ and $\mathrm{Cr}_{\mathrm{f}}$ are the concentrations of $\mathrm{AA}$ and $\mathrm{Cr}$ in the test diets ( $\mathrm{g} / \mathrm{kg}$ of $\mathrm{DM}$ ), respectively. The AID of CP was calculated using the same equation.

The endogenous loss of $\mathrm{N}$ for each AA was measured from pigs fed the $\mathrm{N}$-free diet based on the following equation:

$$
\mathrm{IAA}_{\text {end }}=\left[\mathrm{AA}_{\mathrm{d}} \times\left(\mathrm{Cr}_{\mathrm{f}} / \mathrm{Cr}_{\mathrm{d}}\right)\right],
$$

where $\mathrm{IAA}_{\text {end }}$ is the basal endogenous loss of an $\mathrm{AA}$ ( $\mathrm{g} / \mathrm{kg}$ of $\mathrm{DMI}$ ), and $\mathrm{AA}_{\mathrm{d}}$ and $\mathrm{Cr}_{\mathrm{d}}$ represent the concentrations of $\mathrm{AA}$ and $\mathrm{Cr}$ in the ileal digesta of the pigs fed the $\mathrm{N}$-free diet, respectively. The concentration of $\mathrm{Cr}$ in the $\mathrm{N}$-free diet is represented by $\mathrm{Cr}_{\mathrm{f}}$. The basal endogenous loss of $\mathrm{CP}$ was determined using the same equation.

The average $\mathrm{IAA}_{\text {end }}$ of the 6 pigs fed the $\mathrm{N}$-free diet was used to calculate the SID of AA in all diets. Standardized ileal digestibility was then calculated using the following equation:

$$
\mathrm{SID}=\left[\mathrm{AID}+\left(\mathrm{IAA}_{\text {end }} / \mathrm{AA}_{\mathrm{f}}\right) \times 100 \%\right] .
$$

\section{Statistical analysis}

Data were checked for normality and outliers were identified using the UNIVARIATE procedure of SAS 9.4 (SAS Institute, Cary, NC, USA). An observation was considered as an outlier if the value was more than 3 standard deviations away from the grand mean. In Exp.1, data were analyzed using the MIXED procedure of SAS (SAS Inst. Inc., USA) in two-way analysis of variance. The statistical model included the main effects of inclusion level and adaptation time and their interaction effect. Repeated measurements were considered when analyzing the effects related to adaptation time. Pig was treated as the ex- 
perimental unit. Treatment means were separated using the LSMEANS statement. Orthogonal polynomial contrasts were conducted to determine linear and quadratic effects of inclusion level or adaptation duration. In Exp. 2, data were analyzed using the MIXED procedure of SAS, with a pig as the experimental unit. The statistical model included the fixed effect of diet, and the random effects of period and animal. Treatment means were separated using the LSMEANS statement, and Student $t$ test was used to compare the differences in AA digestibility between corn and SBP. In both experiments, statistical significance and tendency were considered at $\mathrm{p}<0.05$ and $0.05 \leq \mathrm{p}<0.10$, respectively.

\section{RESULTS}

Chemical composition of sugar beet pulp and corn grain Analyzed composition of SBP used in Exp. 1 and 2, and the corn grain used in Exp. 2 are presented in Table 1.

Effects of adaptation time and inclusion level of sugar beet pulp on the apparent total tract digestibility of nutrients and digestible energy value in diet No interactive effects between adaptation time and inclusion level of SBP on the DE value and the ATTD of GE, CP, DM, ash, OM, NDF, and ADF in diets were observed (Table 4). The concentration of DE and the ATTD of GE, DM, ash, and OM in diets linearly decreased $(\mathrm{p}<0.05)$ as the adaptation time increased, regardless of the inclusion level of SBP. The ATTD of DM, ash, OM, and NDF quadratically changed as the adaptation time prolonged from 7 to $28 \mathrm{~d}$ : decreased from 7 to $21 \mathrm{~d}$ and then increased from 21 to $28 \mathrm{~d}(\mathrm{p}<0.05)$. The $\mathrm{DE}$ value of diet varied from 3,295 to $3,259 \mathrm{kcal} / \mathrm{kg}$ (as-fed basis) when the adaptation time increased from 7 to $28 \mathrm{~d}$.

The concentration of DE and the ATTD of GE, CP, DM, ash, and $\mathrm{OM}$ linearly decreased $(\mathrm{p}<0.01)$ as the inclusion level of SBP increased from $0 \%$ to $53.7 \%$, regardless of the adaptation time. The ATTD of NDF and ADF linearly increased ( $\mathrm{p}<$ 0.01 ) as the inclusion level of SBP increased. The concentration of DE varied from 3,529 to $3,075 \mathrm{kcal} / \mathrm{kg}$ (as-fed basis) as the inclusion level of SBP increased from $0 \%$ to $53.7 \%$.

\section{Effects of adaptation time and inclusion level on the digestible energy value and the apparent total tract} digestibility of gross energy and crude protein in sugar beet pulp

An interactive effect $(\mathrm{p}<0.05)$ on the DE value and the ATTD of GE and CP in SBP were observed between the adaptation time and inclusion level (Table 5). The concentration of DE and the ATTD of GE and CP in SBP linearly increased $(\mathrm{p}<0.05)$ as the adaptation time prolonged from 7 to $28 \mathrm{~d}$. The $\mathrm{DE}$ value

Table 4. The effect of adaptation time and inclusion level of sugar beet pulp on digestible energy (DE, $\mathrm{kcal} / \mathrm{kg}$, as-fed basis) value and nutrient digestibility (\%) of experimental diets fed to pigs in Exp. $1^{1)}$

\begin{tabular}{|c|c|c|c|c|c|c|c|c|}
\hline Items & $\mathrm{DE}$ & GE & $\mathrm{CP}$ & DM & Ash & OM & NDF & ADF \\
\hline \multicolumn{9}{|l|}{ Adaptation time } \\
\hline $7 d$ & 3,295 & 87.73 & 84.64 & 87.92 & 53.52 & 90.15 & 74.11 & 72.15 \\
\hline $14 d$ & 3,259 & 86.80 & 83.91 & 86.83 & 48.38 & 89.33 & 73.09 & 73.09 \\
\hline $21 d$ & 3,262 & 86.82 & 83.74 & 86.71 & 46.68 & 89.30 & 71.25 & 71.65 \\
\hline $28 d$ & 3,264 & 86.93 & 84.20 & 86.81 & 46.98 & 89.41 & 73.45 & 72.93 \\
\hline Standard error mean & 10.19 & 0.24 & 0.25 & 0.90 & 0.21 & 0.79 & 0.88 & 0.39 \\
\hline p-linear & 0.008 & 0.009 & 0.377 & $<0.001$ & $<0.001$ & 0.005 & 0.143 & 0.812 \\
\hline p-quadratic & 0.067 & 0.068 & 0.199 & 0.026 & 0.007 & 0.039 & 0.011 & 0.840 \\
\hline \multicolumn{9}{|l|}{ Inclusion level } \\
\hline $0 \%$ & 3,529 & 91.28 & 92.15 & 91.25 & 55.27 & 92.95 & 67.74 & 65.80 \\
\hline $14.6 \%$ & 3,396 & 89.27 & 88.52 & 89.22 & 53.48 & 91.24 & 69.48 & 69.53 \\
\hline $24.4 \%$ & 3,286 & 87.47 & 85.57 & 87.43 & 50.73 & 89.79 & 73.27 & 73.95 \\
\hline $34.2 \%$ & 3,183 & 86.12 & 82.83 & 86.16 & 46.25 & 88.83 & 72.87 & 73.89 \\
\hline $43.9 \%$ & 3,152 & 85.02 & 80.09 & 84.98 & 45.55 & 87.89 & 76.59 & 75.23 \\
\hline $53.7 \%$ & 3,075 & 83.27 & 75.57 & 83.35 & 42.06 & 86.58 & 77.91 & 76.33 \\
\hline Standard error mean & 14.21 & 0.38 & 0.40 & 1.26 & 0.36 & 1.26 & 1.36 & 0.57 \\
\hline p-linear & $<0.001$ & $<0.001$ & $<0.001$ & $<0.001$ & $<0.001$ & $<0.001$ & $<0.001$ & $<0.001$ \\
\hline p-quadratic & 0.009 & 0.913 & 0.058 & 0.827 & 0.499 & 0.740 & 0.809 & 0.121 \\
\hline \multicolumn{9}{|l|}{ Interactive effect } \\
\hline p-day & $<0.001$ & $<0.001$ & $<0.001$ & $<0.001$ & $<0.001$ & $<0.001$ & $<0.001$ & $<0.001$ \\
\hline p-level & 0.06 & 0.067 & 0.508 & 0.004 & $<0.001$ & 0.039 & 0.074 & 0.521 \\
\hline$p-d \times 1$ & 0.329 & 0.341 & 0.515 & 0.318 & 0.725 & 0.233 & 0.498 & 0.248 \\
\hline
\end{tabular}

${ }^{1)}$ Values were least squares mean of six observations per treatment. DE, digestible energy; GE, gross energy; CP, crude protein; DM, dry matter; OM, organic matter; NDF, neutral detergent fibre; ADF, acid detergent fibre. 
Table 5. The effect of adaptation time and inclusion level of sugar beet pulp on the digestible energy (DE, $\mathrm{kcal} / \mathrm{kg}$, as-fed basis) value, ATTD (\%) of GE and CP of sugar beet pulp fed to pigs in Exp. $1^{1)}$

\begin{tabular}{|c|c|c|c|}
\hline Items & $\mathrm{DE}$ & GE & $\mathrm{CP}$ \\
\hline \multicolumn{4}{|l|}{ Adaptation time } \\
\hline $7 d$ & 2,927 & 75.56 & 65.88 \\
\hline $14 d$ & 2,901 & 74.86 & 70.84 \\
\hline $21 d$ & 3,022 & 77.99 & 73.57 \\
\hline $28 d$ & 3,025 & 78.08 & 74.45 \\
\hline Standard error mean & 41.04 & 1.06 & 1.47 \\
\hline p-linear & 0.026 & 0.026 & $<0.001$ \\
\hline p-quadratic & 0.754 & 0.754 & 0.266 \\
\hline \multicolumn{4}{|l|}{ Inclusion level } \\
\hline $14.6 \%$ & 2,982 & 76.95 & 79.16 \\
\hline $24.4 \%$ & 2,889 & 74.55 & 72.53 \\
\hline $34.2 \%$ & 2,869 & 74.08 & 70.31 \\
\hline $43.9 \%$ & 3,042 & 78.54 & 69.02 \\
\hline $53.7 \%$ & 3,061 & 78.98 & 64.92 \\
\hline Standard error mean & 55.13 & 1.39 & 1.74 \\
\hline p-linear & 0.097 & 0.097 & $<0.001$ \\
\hline p-quadratic & 0.060 & 0.060 & 0.385 \\
\hline \multicolumn{4}{|l|}{ Interactive effect } \\
\hline p-day & 0.069 & 0.069 & $<0.001$ \\
\hline p-level & 0.006 & 0.006 & 0.001 \\
\hline$p-d \times 1$ & 0.023 & 0.023 & 0.024 \\
\hline
\end{tabular}

1) Values were least squares mean of six observations per treatment. $D E$, digestible energy; ATTD, apparent total tract digestibility; GE, gross energy; CP, crude protein.

and the ATTD of GE in SBP varied from 2,869 to 3,061 kcal/kg (as-fed basis) and $74.08 \%$ to $78.98 \%$, respectively. The ATTD of CP in SBP varied from $64.92 \%$ to $79.16 \%$.

\section{Ileal amino acid digestibility of sugar beet pulp \\ The AID and SID of CP and all detected AA in SBP were less $(p<0.05)$ than those in corn grain (Table 6).}

\section{DISCUSSION}

Sugar beet pulp sample used in the current experiment contained lower $\mathrm{CP}, \mathrm{EE}$, and TDF values but greater ash content compared with the previous reports $[6,11,19]$. Factors such as the variety of the beet and processing procedure of the SBP can affect the composition of the SBP. The ratio of SDF to TDF for the SBP sample used in this study was $40.7 \%$ and which was greater than that of $32.0 \%$ reported by Zhang et al [19]. This indicated that SBP is an ingredient with high soluble fiber content. It is well known that SDF can be fermented rapidly by the bacteria in the hindgut of pigs to produce short-chain fatty acids $[20,21]$. Therefore, sugar beet pulp was included into the diets fed to sows and growing pigs as a source of soluble dietary fiber.

Effects of inclusion level of sugar beet pulp on the digestible energy value and the apparent total tract digestibility of nutrients in diets

The decreased concentrations of DE value and ATTD of GE

Table 6. The apparent ileal digestibility (AID, \%) and standardized ileal digestibility (SID, \%) of amino acids in corn and sugar beet pulp in Exp. 2

\begin{tabular}{|c|c|c|c|c|c|c|c|c|}
\hline Item & \multicolumn{2}{|r|}{ AID } & SEM $^{1)}$ & $p$-value & \multicolumn{2}{|c|}{ SID } & SEM & p-value \\
\hline Crude protein & 78.47 & 39.20 & 2.12 & $<0.001$ & 82.39 & 50.00 & 1.21 & $<0.001$ \\
\hline Arg & 90.42 & 68.00 & 0.78 & $<0.001$ & 91.61 & 69.26 & 0.77 & $<0.001$ \\
\hline His & 79.93 & 54.31 & 1.34 & $<0.001$ & 82.68 & 57.30 & 1.34 & $<0.001$ \\
\hline lle & 71.22 & 43.88 & 1.30 & $<0.001$ & 75.59 & 50.23 & 1.16 & $<0.001$ \\
\hline Lys & 61.96 & 33.35 & 2.07 & $<0.001$ & 65.45 & 37.03 & 2.09 & $<0.001$ \\
\hline Met & 74.19 & 48.54 & 1.67 & $<0.001$ & 76.65 & 51.62 & 1.58 & $<0.001$ \\
\hline Phe & 79.59 & 56.74 & 1.27 & $<0.001$ & 84.29 & 59.98 & 1.17 & $<0.001$ \\
\hline Thr & 64.46 & 32.51 & 1.50 & $<0.001$ & 71.57 & 40.68 & 1.20 & $<0.001$ \\
\hline Trp & 75.25 & 41.07 & 0.86 & $<0.001$ & 79.90 & 46.22 & 0.88 & $<0.001$ \\
\hline Cys & 73.32 & 45.77 & 1.71 & $<0.001$ & 79.45 & 53.75 & 1.29 & $<0.001$ \\
\hline Glu & 84.48 & 48.49 & 1.35 & $<0.001$ & 85.96 & 60.60 & 1.33 & $<0.001$ \\
\hline Gly & 63.75 & 36.39 & 2.27 & $<0.001$ & 72.70 & 46.51 & 1.49 & $<0.001$ \\
\hline Pro & 64.37 & 41.50 & 2.00 & $<0.001$ & 77.55 & 54.08 & 2.27 & $<0.001$ \\
\hline Ser & 72.92 & 43.88 & 1.46 & $<0.001$ & 77.43 & 47.68 & 1.39 & $<0.001$ \\
\hline Tyr & 74.37 & 54.89 & 3.76 & $<0.001$ & 83.98 & 64.01 & 4.64 & $<0.001$ \\
\hline
\end{tabular}

SEM, standard error mean. 
in diets as dietary SBP level increased from 0\% to 53.7\% agreed with the previous results [19]. Another study showed that the ATTD of GE decreased when the dietary fiber level increased from $12.0 \%$ to $38.0 \%$, in which the fibers are mixture of wheat bran, maize bran, soybean hulls, and SBP [22]. The reduction in energy digestibility with increased dietary fiber level can be attributed to the increased cell wall components from the fiber sources which are less digestible [1]. In addition, high fiber ingredients used in diets can dilute the energy fraction of the feed and then decrease the digestibility of energy and the other nutrients $[7,9]$. Another possible reason may be that the increased digesta viscosity induced by SBP impeded the diffusion rate of nutrients from the lumen to the epithelial cells, which caused a reduction in the absorption of the nutrients [23].

The decreased ATTD of CP, DM, ash, and OM with increased dietary SBP level in our research agreed with Bindelle et al [20], who reported that the ATTD of CP, DM, ash, and OM linearly decreased when a corn-SBM-based diet supplemented with SBP at levels of $0 \%, 10 \%, 20 \%$, and $30 \%$ was fed to growing pigs. It has been reported in rats that a $15 \%$ to $30 \%$ of fiber composition in SBP presents as a form of pectin [24], which can increase digesta viscosity and thus inhibit enzyme activity and possibly increase proteolytic enzyme secretion [25]. The decreased ATTD of CP in diets may be due to the negative effect of NDF level on N digestibility [26]. In addition, increased digesta viscosity and then decreased proteolytic enzymatic digestion of CP were induced by high fiber from SBP [27-29]. Another possible reason for the decreased ATTD of $\mathrm{CP}$ in diets with increased SBP may be due to higher endogenous losses of $\mathrm{N}$ because of increased secretion of endogenous amino acids induced by high fiber [20].

Increased ATTD of NDF with increased dietary SBP agreed with the report that the ATTD of NDF linearly increased when dietary SBP increased from $0 \%$ to $30 \%$ [20] or when dietary wheat bran increased from $9.7 \%$ to $48.3 \%$ [30]. Zhang et al [19] found that the ATTD of TDF, SDF, and IDF increased as the dietary SBP increased from $0 \%$ to $55.0 \%$. This may be due to the increased viscosity of digesta induced by increasing the levels of SBP, which can prolong the digesta passage rate and leave more time for fermentation of fiber in the lower gut by bacteria [31]. Therefore, the ATTD of nutrients in feed is affected by the source and level of fiber.

Effect of adaptation time on the digestible energy value and the apparent total tract digestibility of components in diets

Dietary fiber is mainly fermented in the hindgut of monogastric animals. It has been reported that sows and adult pigs had greater digestibility of fiber than young pigs. The main reasons may be that adult pigs have a larger, more developed intestinal tract and thus, greater intestinal volume which allows for more exposure of feed to enzymes and bacteria and more absorption of nutrients in the small and large intestine [32-34]. For this reason pigs with $85.0 \mathrm{~kg}$ BW were chosen in Exp. 1. However, Kass et al [35] found that digestive capacity was negatively related to the live weight of pigs. The different dietary fiber type of SDF and IDF can be a plausible explanation for the different results among different experiments. Previous studies showed that SDF are more likely to produce modifications in the physico-chemical properties of colonic digesta without changing the colonic microbiota diversity in the proximal colon of monogastric animals than IDF $[9,21,36]$. Other reasons such as inclusion levels of dietary fiber, breed and BW of pig can also affect the results. All factors that affect the ATTD of OM can affect the ATTD of GE and therefore the DE value as the adaptation time increased. In our study, the $\mathrm{DE}$ value and the ATTD of nutrients except for $\mathrm{ADF}$ in the pigs adapted to diets for $7 \mathrm{~d}$ were greater than those adapted for 14,21 , or $28 \mathrm{~d}$. On d 7, the gastrointestinal tract was not well adapted, and more nutrients may be used for bacteria activities, with less excretion to feces.

In our current study, the adaptation time had no effect on the ATTD of CP in the diet, which agreed with a previous study [8], but conflict with a report that the apparent digestibility coefficient of CP in a starch or NSP diet fed to sows for 2 to 5 weeks was greater than that in diets fed to sows only for 1 week [10]. This difference may be due to the different BW of pig, fiber sources and inclusion levels, which would result in different endogenous losses of nitrogen and different synthesis of microbial proteins in the large intestine as the adaptation time increased [8]. The adaptation time had no effect on the ATTD of ADF. Therefore, the main reason for the decreased ATTD of GE as well as decreased DE value is the decreased ATTD of NDF and OM in diet.

\section{Effects of adaptation time and inclusion level on the} digestible energy value and the apparent total tract digestibility of gross energy and crude protein in sugar beet pulp

The ATTD of GE and DE value linearly decreased in the diet, but linearly increased in the ingredient SBP as the adaptation time increased from 7 to $28 \mathrm{~d}$. This difference may be due to the fiber in SBP having greater digestibility compared with the fiber from the corn and SBM in the basal diet, and more short-chain fatty acids were absorbed as the adaptation time increased. The linearly increased ATTD of CP in SBP may be due to the longer adaptation time leading to more $\mathrm{CP}$ being used to synthesize protein for bacterial proliferation in the large intestine of pigs, which resulted in less excretion of $\mathrm{CP}$ in feces [37]. The possible reasons for the decreased ATTD of $\mathrm{CP}$ with increased SBP level may be because the high fiber in SBP increases the specific endogenous losses of AA $[18,37]$. Inclusion level had no effect on the ATTD of GE and DE value of SBP, however, the average value of DE in SBP determined 
in this study was less than that value [11]. The possible reasons for this difference may be due to the different variety of beet used for production of SBP, processing of SBP, and different animals used for evaluating the SBP.

The lower DE value in SBP compared with the corn grain [11] may be mainly due to a combination effect of the high fiber and low EE content in SBP.

\section{Ileal amino acid digestibility of sugar beet pulp}

The AID and SID values of AA in corn grain were in good agreement with previous values [11] except that $90.42 \%$ for the AID and $91.61 \%$ for the SID of Arg were observed, respectively. The AID of all AA but Lys, Met, and Ala in SBP were greater than the values from NRC [11]. The SID of all AA but Ile, Leu, Lys, Met, and Ala in SBP were greater than previously reported values $[11,38]$. Even though containing comparable $\mathrm{CP}$ content to the corn grain, the lower AID or SID of CP and all tested AA in SBP compared with the corn grain indicated that SBP had a poor quality of $\mathrm{CP}$ and AA for pigs.

\section{CONCLUSION}

The results of this study indicated that the ATTD of energy and nutrients were decreased as inclusion rate of SBP increased.

\section{CONFLICT OF INTEREST}

We certify that there is no conflict of interest with any financial organization regarding the material discussed in the manuscript.

\section{ACKNOWLEDGMENTS}

This research was financially supported by the 111 Project (B16044).

\section{REFERENCES}

1. Chiba LI. Sustainable swine nutrition. In: Urriola PE, CervantesPahm SK, Stein HH, editors. Fiber in swine nutrition. 1st ed. Ames, IA, USA: John Wiley and Sons, Inc., Publication; 2013. $260 \mathrm{p}$.

2. Yen JT, Nienaber JA, Klindt J, Crouse DJ. Effect of ractopamine on growth, carcass traits, and fasting heat production of U.S. contemporary crossbred and Chinese Meishan pure- and crossbred pigs. J Anim Sci 1991;69:4810-22.

3. McBurney MI, Sauer WC. Fiber and large bowel energy absorption: validation of the integrated ileostomy-fermentation model using pigs. J Nutr 1993;123:721-7.

4. Adesehinwa AOK. Energy and protein requirements of pigs and the utilization of fibrous feedstuffs in Nigeria: A review. Afr J Biotechnol 2008;7:4798-806.
5. Andersson C, Lindberg JE. Forages in diets for growing pigs 1. Nutrient apparent digestibilities and partition of nutrient digestion in barley-based diets including lucerne and whiteclover meal. Anim Sci 1997;65:483-91.

6. Urriola PE, Stein HH. Effects of distillers dried grains with solubles on amino acid, energy, and fiber digestibility and on hindgut fermentation of dietary fiber in a corn-soybean meal diet fed to growing pigs. J Anim Sci 2010;88:1454-62.

7. Huang Q, Piao XS, Liu L, Li DF. Effects of inclusion level on nutrient digestibility and energy content of wheat middlings and soya bean meal for growing pigs. Arch Anim Nutr 2013; 67:356-67.

8. Longland AC, Low AG, Quelch DB, Bray SP. Adaptation to the digestion of non-starch polysaccharide in growing pigs fed on cereal or semi-purified basal diets. Br J Nutr 1993;70: 557-66.

9. Noblet J, Le Goff G. Effect of dietary fiber on the energy value of feeds for pigs. Anim Feed Sci Technol 2001;90:35-52.

10. Van der Peet-Schwering CMC, Kemp B, den Hartog LA, Schrama JW, Verstegen MWA. Adaptation to the digestion of nutrients of a starch diet or a non-starch polysaccharide diet in grouphoused pregnant sows. J Anim Physiol Anim Nutr 2002;86: 414-21.

11. Committee on Nutrient Requirements of Swine, National Research Council. Nutrient requirements of swine. 11th ed. Washington, DC, USA: National Academy Press; 2012.

12. AOAC International. Official methods of analysis of AOAC International. 18th ed. Gaithersburg, MD, USA: AOAC International; 2006.

13. Thiex NJ, Anderson S, Gildemeister B. Crude fat, diethyl ether extraction, in feed, cereal grain, and forage (Randall/Soxtec/ submersion method): collaborative study. J AOAC Int 2003; 86:888-98.

14. Van Soest PJ, Robertson JB, Lewis BA. Methods for dietary fiber, neutral detergent fiber, and nonstarch polysaccharides in relation to animal nutrition. J Dairy Sci 1991;74:3583-97.

15. Kong C, Adeola O. Evaluation of amino acid and energy utilization in feedstuff for swine and poultry diets. Asian-Australas J Anim Sci 2014;27:917-25.

16. Stein HH, Shipley CF, Easter RA. Technical note: A technique for inserting a T-cannula into the distal ileum of pregnant sows. J Anim Sci 1998;76:1433-6.

17. Li PL, Wang FL, Wu F, Wang JR, Liu L, Lai CH. Chemical composition, energy and amino acid digestibility in double-low rapeseed meal fed to growing pigs. J Anim Sci Biotechnol 2015; 6:37.

18. Stein HH, Seve B, Fuller MF, Moughan PJ, de Lange CF. Invited review: Amino acid bioavailability and digestibility in pig feed ingredients: Terminology and application. J Anim Sci 2007;85: 172-80.

19. Zhang WJ, Li DF, Liu L, et al. The effects of dietary fiber level on nutrient digestibility in growing pigs. J Anim Sci Biotechnol 
2013;4:17.

20. Bindelle J, Buldgen A, Delacollette M, et al. Influence of source and concentrations of dietary fiber on in vivo nitrogen excretion pathways in pigs as reflected by in vitro fermentation and nitrogen incorporation by fecal bacteria. J Anim Sci 2009;87:58393.

21. Molist F, Gómez de Segura A, Gasa J, et al. Effects of the insoluble and soluble dietary fibre on the physicochemical properties of digesta and microbial activity in early weaned piglets. Anim Feed Sci Technol 2009;149:346-53.

22. Le Gall M, Serena A, Jørgensen H, Theil PK, Bach Knudsen $\mathrm{KE}$. The role of whole-wheat grain and wheat and rye ingredients on the digestion and fermentation processes in the gut- a model experiment with pigs. Br J Nutr 2009;102:1590-600.

23. Rainbird RM, Thorne JH, Hardy RWF. Role of amides, amino acids, and ureides in the nutrition of developing soybean seeds. Plant Physiol 1984;74:329-34.

24. Mata YN, Blázquez ML, Ballester A, González F, Muñoz JA. Sugar-beet pulp pectin gels as biosorbent for heavy metals: Preparation and determination of biosorption and desorption characteristics. Chem Eng J 2009;150:289-301.

25. Brunsgaard G, Bach Knudsen KE, Eggum BO. The influence of the period of adaptation on the digestibility of diets containing different types of indigestible polysaccharides in rats. $\mathrm{Br}$ J Nutr 1995;74:833-48.

26. Len NT, Lindberg JE, Ogle B. Digestibility and nitrogen retention of diets containing different levels of fibre in local (Mong Cai), F1 (Mong Cai×Yorkshire) and exotic (Landrace×Yorkshire) growing pigs in Vietnam. J Anim Physiol Anim Nutr 2007;91: 297-303.

27. Jørgensen H, Zhao XQ, Eggum BO. The influence of dietary and environmental temperature on the development of the gastrointestinal tract, digestibility, degree of fermentation in the hind-gut and energy metabolism in pigs. Br J Nutr 1996; 75:365-78.

28. Morel PCH, Lee TS, Moughan PJ. Effect of feeding level, live weight and genotype on the apparent faecal digestibility of energy and organic matter in the growing pig. Anim Feed Sci Technol 2006;126:63-74.

29. Le Goff G, Dubois S, van Milgen J, Noblet J. Influence of dietary fibre level on digestive and metabolic utilisation of energy in growing and finishing pigs. Anim Res 2002;51:245-59.

30. Huang Q, Su YB, Liu L, Piao XS, Li DF. Effects of inclusion levels of wheat bran and body weight on ileal and fecal digestibility in growing pigs. Asian-Australas J Anim Sci 2015;28: 847-54.

31. Dikeman CL, Fahey Jr GC. Viscosity as related to dietary fiber: a review. Crit Rev Food Sci Nutr 2006;46:649-63.

32. Cunningham HM, Friend DW, Nicholson JWG. The effect of age, body weight, feed intake, and adaptability of pigs on the digestibility and nutritive value of cellulose. Can J Anim Sci 1962;42:167-75.

33. Fernández JA, Jørgensen H, Just A. Comparative digestibility experiments with growing pigs and adult sows. Anim Sci 1986; 43:127-32.

34. Lowell JE, Liu Y, Stein HH. Comparative digestibility of energy and nutrients in diets fed to sows and growing pigs. Arch Anim Nutr 2015;69:79-97.

35. Kass ML, Van Soest PJ, Pond WG, Lewis B, McDowell RE. Utilization of dietary fibre from alfalfa by growing swine. I. Apparent digestibility of diet components in specific segments of the gastrointestinal tract. J Anim Sci 1980;50:175-91.

36. Roca-Canudas M, Anguita M, Nofrarías M, et al. Effects of different types of dietary non-digestible carbohydrates on the physico-chemical properties and microbiota of proximal colon digesta of growing pigs. Livest Sci 2007;109:85-8.

37. Schulze H, van Leeuwen P, Verstegen MWA, et al. Effect of level of dietary neutral detergent fiber on ileal apparent digestibility and ileal nitrogen losses in pigs. J Anim Sci 1994;72:2362-8.

38. Eklund M, Rademacher M, Sauer WC, Blank R, Mosenthin R. Standardized ileal digestibility of amino acids in alfalfa meal, sugar beet pulp, and wheat bran compared to wheat and protein ingredients for growing pigs. J Anim Sci 2014;92:1037-43. 